УДК $159.922 .73-057.874$

DOI:

Зоряна Спринська, кандидат психологічних наук, дочент кафедри практичної психології Дрогобицького державного педагогічного університету імені Івана Франка

Ольга Федьович, студентка гр. П-41 Б, спеиіальності психологія Дрогобииького державного педагогічного університету імені Івана Франка

\title{
РОЛЬ ПРОЦЕСУ НЕВРОТИЗАЦІЇ У ПОЯВІ СОЦІАЛЬНОЇ ФРУСТРОВАНОСТІ В СТАРШОМУ ШКІЛЬНОМУ ВІЩІ
}

У статті йдеться про явище соціальної фрустрованості, шуо виникає у стариому шкільному віці та визначається провідна роль невротизачії у ичьому процчесі. Облрунтовано, щзо процес невротизації проявляється у дезорганізуючих емоційних станах в режимі пригнічення психіки, окреслено проблему етимологї невротичних розладів особистості та особливостей переживання нею фрустраційних станів. Досліджено, ичо формування самовизначення передбачає існування низки варіантів його прояву, цүо, своєю чергою, привело нас до думки про перевагу проведення індивідуально-орієнтованого дослідження з метою вивчення показників і об'єктів незадоволеності старшокласника у його сочіальній реалізованості, а саме його соціальної фрустрованості, яка знаходиться в тісному взаємозв'язку із невротичними проявами особистості.

Ключові слова: сочіальна фрустрованість; невротизація; учні старшого икільного віку.

Jim. 7.

Zoryana Sprynska, Ph.D.(Psycology), Associate Professor of the Practical Psychology Department Drohobych Ivan Franko State Pedagogical University

Olha Fedovych, Student P-41 B, of specialty Psychology Drohobych Ivan Franko State Pedagogical University

\section{THE ROLE OF THE NEUROTICIZATION PROCESS IN THE EMERGENCE OF SOCIAL FRUSTRATION IN THE SENIOR SCHOOLAGE}

The article deals with the phenomenon of social frustration. It occurs in senior school age and defines the leading role of neuroticism in this process. It has been substantiated that the process of neuroticism manifests itself in disorganizing emotional states in the mode of mental depression. It is outlined the problem of etymology of neurotic disorders of personality and peculiarities of experiencing frustration states. It has been researched that the formation of self-determination implied the existence of a number of variants of its manifestation. In turn, it led us think about the advantage of conducting an individually oriented research in order to research the indicators and objects of dissatisfaction of the senior school-aged pupils in his social reality; social frustration is closely related to the neurotic manifestations of personality.

It has been found out an interesting fact that in groups with high, medium and low levels of neuroticism the general trends in dissatisfaction with certain areas of life: the area of satisfaction with their study; position in society; spend of leisure time; the possibility of choice in the profession. The greatest contrast of expression of social frustration of senior school-aged pupils is observed in the spheres of satisfaction with relationships with classmates; conditions of educational activity; financial condition; relationships with parents and friends; the opportunity to spend interesting vacations; a way of life as a whole.

Thus, the research has confirmed our assumption about the correlation of the level of neuroticism and social frustration of pupils of senior school age, characterized by meaningful features of the manifestation of neurotic disorders (depression, asthenia, behavioral disorders, autonomic disorders, sleep disorders, anxiety) and typical complexes of symptoms of interpersonal interaction.

Keywords: social frustration; neuroticism; pupils of senior school age.

П остановка проблеми. Гуманізація сфери освіти в українській державі вимагає постійного звернення до особистості учня. Що стосується характеристики особистості старшокласника, то можна помітити певний схематизм і категоричність. Вказується на завершеність розвитку старшокласників як у фізичному так і в духовному відношенні, намічається їх тотожність із дорослим станом, стираються протиріччя, які властиві підлітковому віку, підкреслюється певна гармонія "тілесного" та “духовного”, встановлення стабільного ставлення до оточуючих, взаєморозуміння 3 батьками й вчителями.

Але через соціально-економічні зміни в суспільстві, старшокласникам не завжди вдається 


\section{РОЛЬ ПРОЦЕСУ НЕВРОТИЗАЦІЇ У ПОЯВІ СОЦАЛЬНОЇ ФРУСТРОВАНОСТІ В СТАРШОМУ ШКІЛЬНОМУ ВШЦ}

реалізуватись у відповідному напрямку. Форми такої невідповідності носять часто небезболісний характер і можуть виражатись у різноманітних фрустраційних станах незадоволення. Досить часто подібні прояви виступають наслідком особистісних властивостей дитини, які нашаровуються на реальні проблемні ситуації в житті і призводять до виникнення невротичних станів. Також цікавим виявляється факт постійного збільшення невротичних школярів, які вимагають постійної уваги з боку шкільного психолога в плані удосконалення засобів та методів діагностики і профілактики невротичних розладів.

Методологічну основу нашого дослідження склали положення про взаємодію зовнішніх та внутрішніх факторів становлення особистості старшокласника (Л.І.Божович, М.Й. Боришевський, I.C. Кон, В.В. Столін та ін.); розгляду етіології станів психічної дезадаптації в контексті взаємодії 3 індивідуально-типологічними особливостями особистості (Ю.О.Александровський, Б.Д. Карвасарский, Л.М. Собчик та ін.); оцінки провідних особистісних тенденцій вираженості невротичного (патохарактерологічного) розвитку особистості в старшомушкільномувіці(Н.Н. Марута, Б.В. Михайлов, В.В. Седнев на ін.).

Мета статті - окреслити роль процесу невротизації у появі соціальної фрустрованості в старшому шкільному віці.

Виклад основного матеріалу дослідження 3 повним обгрунтуванням отриманих наукових результатів. Говорячи про невротизацію особистості як специфічну форму підготовки іiі переходу у невротичне захворювання, слід сказати, що невротизація проявляється у дезорганізуючих емоційних станах в режимі пригнічення психіки. Тут слід назвати дистимію, депресію, апатію, гіпотимію, тривогу, страх та інші. Ці досить різні за змістом емоційні стани мають низку загальних ознак:

- особистість практично не реагує на зовнішні впливи, окрім допомоги дезорганізуючого емоційного стану, який може посилюватися під впливом різноманітних стимулів, як позитивних так й негативних;

- чим сильніше навіювати сміливість тому, хто переживає стійкий страх, тим страшніше йому стає;

- у такому режимі енергетичному режимі перестає справлятися інтелект людини, і при цьому його роль в оцінці зовнішніх впливів та переживань особистості практично не помітна. Розум і воля не допомагають людині швидко й успішно подолати неадекватність емоційних станів та надати їм комунікабельну форму;
- для відтворення емоційної норми потрібен час, спокій, допомога оточуючих, а інколи навіть й лікувальна.

Додамо, що різні за своїм проявом розлади станів мають схожу механіку: відсутній нормальний зв'язок між інтелектом і емоціями. Інтелект недооцінює потрібним чином зовнішні внутрішні впливи, не виявляє їх значущість для особистості. Його керуючі команди не включають адекватні емоційні програми та напрацьовані при житті стереотипи емоційної поведінки. Замість адекватних емоційних програм і стереотипів весь час автоматично вступає в дію один й той же стереотип, який властивий особистості. ІЇ̈ поведінка стає неадекватною, і при цьому вона не обумовлена явними реальними причинами.

Що стосується соціальної фрустрованості особистості, яка виражається у незадоволеності соціальними досягненнями в основних аспектах життєдіяльності, то часте повторення пї переживання як раз й може привести до глибоких порушень в адекватності оцінки подій та власної поведінки. До соціальних досягнень життєдіяльності особистості можна віднести іiі досягнення у сферах навчання, стосунків з іншими людьми, взаємовідношень із суб'єктами своєї професійної діяльності та ін.

В старшому шкільному віці, коли “почуття дорослості” заставляє юнака проявляти свою самостійність у вирішенні життєвих проблем, соціальна фрустрованість як раз й має тенденцію загостреного появу в силу особливостей юнацького бажання “володіти світом" та проявляти активну реакцію на різні події оточуючого життя.

Психічний стан, який викликається фрустратором, знаходиться під впливом цього фрустратора, i, в тому випадку, коли цей фрустратор носить соціальний характер, то ми говоримо про соціальну фрустрацію. В більшості випадків фрустраційний стан переживається особистістю як: позбавлення (як відсутність необхідних засобів для досягнення мети або задоволення потреби); втрата (може бути зовнішня і внутрішня в залежності від обставин); конфлікт (який проявляється так само у внутрішній або зовнішній формі). Ми повинні сказати, що психічні стани при втраті, позбавленні і конфлікті переживаються залежно від їх змісту, сили і значущості.

Фрустрація розрізняється не тільки за своїм психологічним змістом або спрямованістю, але й за тривалістю. Психічні стани, які характеризують фрустрацію, можуть бути й короткими спалахами 


\section{РОЛЬ ПРОЦЕСУ НЕВРОТИЗАЦЇ У ПОЯВІ СОЦАЛЬНОЇ ФРУСТРОВАНОСТІ В СТАРШОМУ ШКІЛЬНОМУ ВІЦІ}

агресії або депресії афективного типу, а можуть бути й тривалими станами настрою, при цьому залишаючи помітний слід в особистості людини [4].

Фрустрація, як і інші психічні стани можуть бути типовими для характеру людини, або не типовими, які виражають початок виникнення нових рис характеру, а також епізодичними. Так, агресивний стан більш характерний для людини нестриманої, грубої, а депресія - для людини невпевненої в собі. Однак, агресія може бути й у людей стриманих, що стали нестриманими після частих і тривалих фрустрацій. Наприкінець, бувають такі фрустрації, які навіть у "мирної" людини викличуть агресію, проте цей стан не проникає всередину людини, залишаючись лише ситуаційним епізодом.

Насамперед, потрібно вказати ті випадки, коли фрустратори не викликають фрустрацію. В літературі вони часто позначаються як толерантність, тобто як терплячість, витривалість, відсутність тяжких переживань та різних реакцій, не дивлячись на наївність фрустратора.

Соціальна включеність старшокласника в життя слугує показником розвитку особистості, а саме критерієм ii соціальної зрілості, яка виражається в потребі “реалізації не себе в суспільстві, а себе для суспільства” $[2,7]$.

В ранній юності створюються найбільш сприятливі умови для формування потреби у соціальній реалізації в єдності трьох компонентів $[1,25]$. Основа когнітивного компоненту-науковий світогляд, який активно формується в юнацькому віці. Його визначають узагальнююча оцінка оточуючого світу, пізнання соціальних норм (правових і моральних), що регулюють поведінку людини в цьому світі, ставлення до цих норм і правил. Мотиваційний компонент соціальної реалізованості включає якісний стрибок у розвиток самосвідомості - на перший план виступають питання, пов'язані із усвідомленням свого місця в суспільстві, відповідальності за свою поведінку, тобто відбувається своєрідне “примірювання" себе до суспільства. На базі розвинутої самосвідомості формуються суспільно значущі мотиви соціальної діяльності у юнаків та дівчат. На основі сформованого наукового світогляду та розвинутої самосвідомості, відбувається вибір та здійснення юнаками і дівчатами певної лінії поведінки, яка складає поведінковий компонент соціальної реалізованості $[5,18]$.

Отже, особистісне самовизначення старшокласника виступає своєрідною спробоювідповісти самому собі на питання, який я $\epsilon$, що я за людина, яке підіймається у зв'язку із наступаючою дорослістю і новими вимогами, які вона представляє людям.

Підкреслюючи багатоплановість самовизначення старшокласника, ми виділяємо в ньому якості головної ознаки прагнення суб'єкта визначити себе в світі, тобто зрозуміти себе і свої можливості поряд із розумінням свого Я $\mathrm{i}$ призначення в житті $[3,29] .3$ цього приводу С.Л. Рубінштейн говорив, що ключове значення набуває положення розгляду особистості не як такої, що формує своє Я, “дивлячись” на інших, але й такої, яка не може бути розкрита через відношення лише до самої себе: "Інші люди в їх діяльності виступають як фокуси або центри, навколо яких організується світ людини" [6, 236]. Ми вбачаємо в цьому безпосередній особистісний аспект, оскільки визначити себе в світі - означає не тільки знайти своє призначення як члена суспільства, але й визначитись серед інших людей, які поряд і певним чином впливають на нас.

В контексті такого вивчення проблеми Е. Еріксон вводить поняття "психосоціальна ідентичність" особистості [7, 117]. В побудові цього складного теоретичного конструкта, який увібрав у себе й клінічний досвід Е. Еріксона, міститься низка вузлових моментів, де стає можливим його перехід на мову емпіричних еквівалентів: самовизначення (пошук ідентичності) не може здійснюватись “ізольованим” суб'єктом, поверненим своїм внутрішнім поглядом всередину себе.

Сприймаючи себе відносно існування інших, в поняттях соціально значимого, індивід починає формуватись як особистість (групова ідентичність). Це положення відкриває можливість інтерпретації поняття на мові просторово-часових категорій, які відображають смислові уявлення суб'єкта про світ та його структурованість, систему відношень 3 оточуючими людьми та динаміку цих основних життєвих відносин у часі відповідно із диференціацією його на минуле, теперішнє та майбутнє.

Ще один важливий момент, яким ми користуємося у своєму дослідженні: формування самовизначення передбачає не будь-яку єдину генеральну лінію становлення, а існування низки варіантів його прояву. Це й привело нас до думки про відому перевагу проведення індивідуальноорієнтованого дослідження 3 метою вивчення показників і об'єктів незадоволеності старшокласника у його соціальній реалізованості, а саме його соціальної фрустрованості, яка знаходиться в тісному взаємозв'язку із невротичними проявами особистості. 


\section{РОЛЬ ПРОЦЕСУ НЕВРОТИЗАЦІЇ У ПОЯВІ СОЦАЛЬНОЇ ФРУСТРОВАНОСТІ В СТАРШОМУ ШКІЛЬНОМУ ВШЩ}

Отже, аналіз проблеми невротизації в аспекті висвітлення психологічних особливостей становлення особистості старшокласника дозволив нам виділити чинники переживання юнаком внутрішніх протиріч, які визначають зону його особистісного розвитку. Ці протиріччя обумовлені зміною соціальної ситуації розвитку, а відповідно й провідного виду діяльності та комплексом психологічних новоутворень, які дозволяють юнаку як і дорослому, проявляюти свою самостійність та ініціативність.

Переживаючи внутрішні протиріччя, старшокласник активізує свою рефлексію, що може сприяти породженню відчуття провини, невпевненості у собі, замкненості, постійного незадоволення собою. Ці риси можуть закріпитися і поступово перетворитися в сталі якості, котрі в сукупності сприятимуть виникненню комплексу неповноцінності, який може супроводжуватися сильними афективними внутрішніми переживаннями. Виникаючи в період високої емоційності, вони можуть потайки зберігатися, i, в подальшому, перерости в невротичний стан психіки особистості, який може набути сталої хронічної форми, а відповідно зробити людину дезадаптованою до соціальних впливів.

Проведене дослідження відкриває перспективи подальшої роботи над проблемою, а саме таких аспектів як вивчення індивідуально-типологічних особливостей особистості старшокласника, стилю їх міжособистісної взаємодії, оцінки рівня емоційно-особистісної дезінтеграції, виявлення зони психотравмуючих переживань та суті психологічного конфлікту, оцінки динаміки невротичних розладів та ефективності терапії не тільки в старшому шкільному віці, але й на попередніх етапах шкільного віку.

\section{ЛІТЕРАТУРА}

1. Бондаренко О.Ф. Психологічна допомога особистості. Харків, 1996. 240с.

2. Бондаренко А.Ф. Социальная терапия личности (психосемантический подход). Киев, $1991.89 \mathrm{c}$.

3. Занюк С.С. Психологія мотивації та емоцій. Луцьк, 1998.132c.
4. Психічне здоров'я особистості: результати оцінювання та рекомендації для інтеграції охорони психічного здоров'я в систему первинної медичної допомоги та громадські платформи в Україні. Київ, 2017. 146 с.

5. Піроженко Т.О., Соловйова Л.І., Карабаєва I.I. Реалії вибору дитиною соціально значущих цінностей: посібник. Київ, 2017. 64 с.

6. Рубинштейн С.Л. Проблемы общей психологии. Москва, 1973. 423 с.

7. Эриксон Э. Идентичность: юность и кризис. Москва, 1996. 336 с.

\section{REFERENCES}

1. Bondarenko O.F. (1996). Psykholohichna dopomoha osobystosti [Psychological assistance to the individual]. Kharkiv, 240p. [in Ukrainian].

2. Bondarenko, A.F. (1991). Sotsyalnaia terapyia lychnosty (psykhosemantycheskyi podkhod) [Social therapy of personality (psychosemantic approach)]. Kyev, 89 p. [in Russian].

3. Zaniuk, S.S. (1998). Psykholohiia motyvatsii ta emotsii [Psychology of motivation and emotions]. Lutsk, 132p. [in Ukrainian].

4. Psykhichne zdorovia osobystosti: rezultaty otsiniuvannia ta rekomendatsii dlia intehratsii okhorony psykhichnoho zdorovia $v$ systemu pervynnoi medychnoi dopomohy ta hromadski platformy $v$ Ukraini [Mental health of the individual: evaluation results and recommendations for the integration of mental health care into the primary care system and public platforms in Ukraine]. Kyiv, 2017. 146 p. [in Ukrainian].

5. Realii vyboru dytynoiu sotsialno znachushchykh tsinnostei: posibnyk [The realities of the child's choice of socially significant values: a guide]/ T.O. Pirozhenko, L.I. Soloviova, I.I. Karabaieva [ta in.] ; ed. T.O. Pirozhenko. Kyiv, 2017. 64 p. [in Ukrainian]

6. Rubinshteyn, S.L.(1973). Problemyi obschey psihologii [Problems of general psychology].Moscov, 423 p. [in Russian].

7. Erikson, E. (1996). Identichnost: yunost $i$ krizis [Identity: youth and crisis]. Moscov, 336 p. [in Russian].

Стаття надійшла до редакції 22.10.2019

\section{$\cos 80 \operatorname{son} \cos 8080 \cos 8080 \cos 8080 \cos 8080 \cos$}

“Безмежна надія і ентузіазм - головне багатство молоді".

Рабіндранат Tाагор

бенгальський та індійсъкий писъменник,

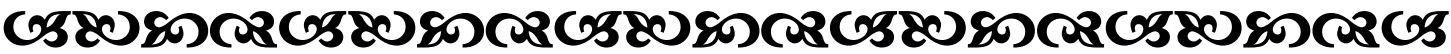

